\title{
A la Recherche du Word Order not quite perdu
}

Gregersen, Frans; Pedersen, Inge Lise

Published in:

Textual Parameters in Older Languages

Publication date:

2000

Citation for published version (APA):

Gregersen, F., \& Pedersen, I. L. (2000). A la Recherche du Word Order not quite perdu. In Textual Parameters in Older Languages (pp. 393-431). John Benjamins Publishing Company. 


\title{
A la Recherche du Word Order Not Quite Perdu
}

\section{A methodological progress report*}

\author{
Frans Gregersen and Inge Lise Pedersen \\ University of Copenhagen
}

\begin{abstract}
This chapter discusses the origin, historical development, and contemporary status of a particular word order signal for the status of a clause as subordinate in Danish, viz. the placement of the so-called sentence adverbials, primarily negation, in relation to the verb. Originally, Danish, like English, had no such signal for subordination; we show how the new word order develops until it is close to obligatory in written standard Danish around the middle of the 19th century. We then turn to dialect evidence and data from a sociolinguistic study of the speech of contemporary urban Copenhageners. Although the old word order still exists in modern spoken Copenhagen Danish, it is specialized: virtually all examples are from that-clauses and causal clauses. No clear and unambiguous explanation is found for the distribution of the two word order variants in terms of the speaker variables of sex/gender, social class, or age group. The chapter concludes by discussing the Danish data as part of a larger - and still unfinished - picture of the use of subordination signals in the Germanic languages.
\end{abstract}

\section{Introduction: The Problem}

By the turn of the 20th century, the modernist movement was challenging the 
supremacy of Latin as a model for the linguistic description of the Germanic languages. It is well known by general linguists that the Danish phonetician and professor of English, Otto Jespersen, participated in this movement, and helped to hammer out the paradigm in a form that made it palatable and practicable for language teachers (cf. Gregersen 1991). For professional reasons, Jespersen was not particularly concerned with the grammar of Danish. ${ }^{1}$ However, he used to point to the Danish grammarian H. G. Wivel as a fellow fighter, and for good reason: because of his 1901 attack on Kr. Mikkelsen as the prime representative of what Jespersen was later to brand as the tradition of 'squinting grammar', Wivel has been hailed as the first Danish structuralist grammarian (Hjelmslev 1928:109f, cf. Diderichsen 1965 for a reappraisal).

Wivel's (1901) book profoundly influenced the Danish grammatical tradition. In addition to his wholesale destruction of the Latin tradition, he conceived of Danish as a language which uses word order as a carrier of meaning. One of Wivel's lasting insights in this regard was that Danish has a formal defining difference between primary (or main) and subordinate clauses.

The Latin tradition makes use both of a logical criterion based on dependency (viz. that independent sentences are main clauses, and dependent sentences are subordinate clauses; Mikkelsen 1911[1975]: 487) and a syntactic criterion (ibid). The latter stresses the fact that a subordinate clause is different from a primary clause in virtue of its being a recognizable constituent of a main clause. This definition is not without its problems, however, since relative clauses, which obviously are subordinate clauses, are strictly speaking not members of the primary sentence but rather function as adjectival extensions of the NP constituent.

In contrast, Wivel looked to topology, i.e. the fixed patterns of sentence members, hence also of word order (cf. the 'slot and filler' tradition of analysis), for the defining difference between primary and subordinate clauses. $\mathrm{He}$ found his crucial criterion in the placement of sentence adverbials. Danish has at least three kinds of adverbials: 1) circumstantials and 2) manner adverbials, neither of which may ever be placed in the adverbial position adjacent to the finite verb, and 3) sentence adverbials, which usually occupy this slot. (1)-(3) exemplify the three kinds of adverbials in present-day Danish:

(1) han ville ikke have spillet henne på skolen lit.: he would not have played over at the school topology: S Vfin. Sentence Adverb (SA) Vinf. Vinf. Circumstantial Adv. 
(2) han ville ikke have spillet så højt

lit.: he would not have played so loudly

topology: S Vfin. SA Vinf. Vinf. Manner Adv.

(3) han ville ikke have spillet

lit.: he would not have played

topology: S Vfin. SA Vinf. Vinf.

Wivel noted that the sentence adverbial (henceforth, SA) placement varies according to the type of the clause. In (4) below, there is a difference in word order between the first (main) and the second (subordinate) clause, in particular between the relative positions of the finite verb and the SA:

(4) jeg har ikke sagt at jeg ikke vil have det

lit. I have not said that I not will have it = I haven't said that I won't have it

topology: S Vfin. SA Vinf. O=Sub.Sentence: conj. S SA Vfin. Vinf. O

In the main clause, the topological format is Vfin. SA, whereas the subordinate clause has the format SA Vfin. This word order difference between the two clause types led Wivel to define them topologically:

Indeed, it will turn out that while sentences without a preposed adverb, etc. as a rule are independent, sharply isolated from the surrounding sentences of the same kind by intonation and pause, the sentences with a preposed adverb, etc. are almost always part of a combination of clauses which includes a sentence of the other kind. The semantic relationship will most often be that the former sentences express the main thought while the latter express additional thoughts. Thus it is natural to use the well-known names of primary sentence and subordinate sentence for these two sentence types, primary sentence for the type without a preposed adverb (but otherwise with by and large a more plastic word order) and subordinate sentence for the type with a preposed adverb (but otherwise a more rigid word order, cf. $\S 300){ }^{2}$ (Wivel 1901: 305f)

Wivel was not the first Danish grammarian to note this formal difference, ${ }^{3}$ although he was the first to make it a cornerstone of his definitions. Nor was he by any means the last. Once formulated, the topological difference became a firmly entrenched tradition of Danish grammar.

Diderichsen (1946) lists two formal characteristics of primary and subordinate clauses: the primary clauses have a topological first position called the fundament, the subordinate clauses do not. Moreover, primary clauses have 
the sentence adverbials placed after the verb, while subordinate clauses have the sentence adverbials before the verb (Wivel's 'preposed' adverbials).

\begin{abstract}
The examples in $\$ 64$ have all been taken from independent sentences. If one includes in the investigation sentences which are members of other sentences, one will find that most of these have a simpler structure in that they do not have any fundament field and furthermore have a different order of the members in the nexus field. [Diderichsen divided the Danish sentence into three topologically different 'fields', viz. the fundament field with one position only, the nexus field, and the content field, with three positions each FG \& ILP]. Thus it is only the content field which does not vary across sentence types. We have to propose two main types of sentences: Subordinate sentences $(\$ 72)$ which lack the fundament field and manifest the order of members s-a-v (a-s-v) [i.e., subject-sentence $a$ dverbial-finite verb] in the nexus field, and primary sentences $(\$ 73)$ which have a fundament field (even though the positions are not always filled) and the order of members v-s-a (v-a-s) both in the nexus field and the content field. ${ }^{4}$ (Diderichsen 1946: 185)
\end{abstract}

In the Swedish grammatical tradition, the parallel definition of subordinate clauses goes back to Natanael Beckman's Svensk Språklära (1916). Beckman proposes that subordinate "sentences" may be recognized using three criteria, the first syntactic, the other two formal:

1. Subordinate sentences are members of other sentences (primary or main sentences) (Beckman 1916[1964]: 234).

2. As a rule, a subordinate sentence will be introduced by a subordinating conjunction or a relative pronoun. ${ }^{5}$

3. Subordinate word order: certain adverbs are preposed, viz. they are placed before the verb in the subordinate sentences.

Beckman's criteria for Swedish seem to work very well for written Danish. However, spoken Danish has instead of one structure in the subordinate sentences two alternative possibilities, as exemplified in (5) and (6):

(5) jeg har ikke sagt at jeg ikke vil have det

lit. I have not said that I not will have it = I haven't said that I won't have it topology: S Vfin. SA Vinf. O=S: conj. S SA Vfin. Vinf. O

(6) jeg har ikke sagt at jeg vil ikke have det

lit.: I have not said that I will not have it

topology: S Vfin. SA Vinf. O=S: conj. S Vfin. SA Vinf. O 
In (5) we have the characteristic Subordinate Clause Word Order (henceforth SCWO). In (6), however, we have in the second clause the topology characteristic of main clauses, even though the clause is obviously semantically dependent, has a conjunction, and functions as a sentence member of the first clause. Thus in spoken Danish, the word order thought to be typical of main clauses may be used in subordinate clauses as well. When this word order is used in dependent clauses, we shall henceforth use the abbreviation MCWO (for Main Clause Word Order).

The description and explanation of these facts have been a matter of considerable debate (Heltoft 1986; Platzack 1987a, 1987b). In this chapter, we will be concerned with two problems raised by subordinate word order in Danish:

1. Subordinate word order is not original in Danish, but rather has evolved to become a criterion for subordinate clauses.

2. Subordinate word order distinguishes the modern Danish written language from the modern Danish spoken language, in that some syntactically subordinate clauses have main clause word order in the spoken language whereas this is not normally the case in written texts.

In what follows, we attempt to sketch some explanatory models for this particular combination of facts by drawing on methods of historical linguistics and sociolinguistics.

\section{The Evolution of Subordinate Word Order in Danish}

The function of subordination is to create complex propositions. The idea of having a dependent clause is precisely to modify the primary proposition in certain respects, either to include some background information (often given in the form of parenthetical relative clauses), or to package both reasons and circumstances for the main proposition under the command of only one topmost S-node.

Because of the complexity involved, subordination has been considered a sign of a learned style (Blatt 1957:45 with note 2, and p. 47), a characteristic of a middle class elaborated code (Bernstein 1959 (1971):55), or both. Obviously, style is not independent of genre. Thus the first problem we face when conducting an investigation of the evolution of subordinate word order in 
Danish is to find appropriate and representative text types to make up the data corpus.

All researchers agree that whatever the governing principle was for word order in the earliest Nordic texts, it was not the distinction between primary and subordinate clauses. There were certainly different word orders, probably depending on what was topicalized or other pragmatic factors, but the conditions for variation did not involve any distinction between clause types (see Nygaard 1966:344 cf. p.371). The second problem is thus that of sketching the evolution in time of the subordinate word order. It is not present in the oldest written sources, but it is indisputably - albeit not invariably, cf. section 3 below - present now. When did it emerge, and what is the trajectory of its evolution?

\subsection{Representativity Versus Historicity}

It is a fundamental tenet of any comparative method that one should only compare likes. For diachronic linguistic comparisons, this often gives rise to a paradox, since the various periods in the history of e.g. Danish have been characteristically connected with one or more dominant text types. Thus the runic inscriptions of the earliest Danish are considered to make up a period of their own. Similarly, the law texts of the Middle Ages are the dominant texts for the next period, but the two text types could not be more different. Consequently, we face a dilemma: if we were to take the runic inscriptions as our point of departure for a sketch of the development of Danish, keeping the text type constant, we would for later periods be confined to a data set consisting of what is written on the tombstones of graveyards! On the other hand, if we do not keep our text types constant, we violate the principles of comparison and run the risk of comparing styles instead of stages (cf. a similar discussion in Pettersson 1985:184ff).

This is even more apparent when we take the earliest Danish full texts as our point of departure. The laws of Modern Danish clearly make up a text type of their own, heavily influenced by chancellery juridical traditions which were ultimately based on the Latin tradition of canonical law. This makes the text type as such one which in some respects is quite remote from everyday written language, to say nothing of spoken Danish. Taking only law texts as the data for a history of Danish would result in a gross exaggeration of the Latin influence on the Danish language. 
When one chooses to build up a corpus consisting of representative texts from different periods for the investigation of the history of Danish, one has in fact violated the ground rule of only comparing likes. If, on the other hand, we hold the text type constant, we would be comparing the supposedly central text types of one period with markedly marginal text types of a later period. This is particularly obvious in the case of religious texts. In today's Scandinavia, secularization has seen to it that religious texts like Bible translations and sermons are marginal as text types, even though various versions of the Bible intertextually pervade all literature and all artistic prose. In the Middle Ages and the period of orthodoxy dominating post reformation Denmark, however, the religious text types were central, if not the only ones with the ordinary language user as their addressee, and consequently cannot be left out of consideration.

In other words, when we compare dominant text types from the various epochs, we by the same token choose to ignore genre specifics which might be relevant. What we keep constant, however, is what one might characterize metaphorically as the mental weight or the textual pertinence for the language user. In the epochs we delineate below, different text types were central for the consciousness typical of the epoch. Thus we may broadly say that as the epochs change, so the typical Danish written language users (readers) not only gain access to new text types in Danish, but also develop new preferences for the use of specific text types for their construal of cultural identity. Typically, we see a development from religious text types towards literary prose and mass media. In basing our selection of texts on the criterion of dominance in a given epoch, we have thus consciously sinned against the demand of comparing only like genres. We have instead chosen to select texts according to what may be called socio-psychological comparability.

The following tentative periodization is based mainly on (1) the gradual Danification of until then predominantly or exclusively Latin or Middle Low German domains, progressively resulting in a variety of text types, and (2) the growth of literacy, which is alleged to lead to changes in ascribed values and to influence social attitudes towards written versus spoken language: 
Table 1. A tentative periodization of Danish language history

Period I

Old Danish: before 1100

Writing system: Runes

Text types: Memorial stones, brief inscriptions on wooden or metal objects, mostly ownership marks

Period II

Middle Danish: $1100-1500$

Writing systems: The Latin alphabet, hand writing, some extant knowledge of runic writing

Text types: Manuscripts of laws, religious literature (legends, prayer books, books of sermons), literature about medicine and encyclopedic literature, diplomae, chronicles, courtly poetry

Literacy: Restricted to clerically trained persons

Period III

Reformation and Orthodoxy: $1500-1700$

Writing systems: The Latin alphabet used in hand writing and book printing (in the Gothic types) ${ }^{6}$

Text types:

1. Printed: Religious literature: Bible translations, books of sermons, hymn books

Secular: Polemical treatises, enlightening and entertaining literature as well as juridical texts: collections of laws

Dictionaries and grammars

2. Manuscripts: Diplomae and private letters

Literacy: The printing press makes books more accessible and has a standardizing effect. The urban population becomes more literate.

Language attitudes: Danish is evaluated more positively and is 'cultivated' with the first dictionaries and grammars.

Period IV

Enlightenment: $1700-1800$

Writing systems: As in period III

Text types: New genres are written in Danish, new domains are added: drama, essay (Holberg) and popular science (Sneedorff).

Literacy: Schooling makes the population as a whole more literate, but there is still a large difference between town and country.

\section{Period V}

The 19th Century: $1800-1900$

Writing systems: More use of the Latin printing types which become universal at the end of the century

Text types: Danish is used in all domains 
Literacy: In this period, the Danish population as a whole becomes literate due to the increased efforts for general education. Explicit norms for orthography are discussed during most of the century to become fixed only at the end (the first normative orthographical dictionary dates from 1891). Newspapers are numerous; writing is the central medium of information.

Period VI

The 20th Century: $1900-2000$

First half: Writing still central

Second half: Writing begins to lose importance to the electronic (audiovisual) media; a new (so-called secondary) orality (cf. Ong 1977:298f) influences writing as well; more focus on rhetoric, whether written or spoken.

\subsection{Text Corpus}

The text samples for this study were selected to represent central text types of periods III-VI according to Table 1, and at the same time texts relatively close to spoken language. Therefore we have selected narrative texts and letters, and (in a more rhetorical orality) sermons and speeches, rather than law texts and texts originating from the Royal Chancellery. There are no text samples from period I and II for two reasons. First, in the medieval period, main clause word order is the normal word order both in main clauses and subordinate clauses; only in the 16th century does one find a substantial number of clauses with subordinate clause word order. Second, our interest is in following the development of the standard language, and the present norm of written Danish originates essentially in the 16th century.

The excerpted text samples are of varying lengths. With the exception of Anders Sørensen Vedel 1581, which is a rather short text, the samples consist of at least 100 tokens from each text. The texts by Grundtvig constitute an exception by being longer. This is due to the fact that the proportion of main clause word order was much greater in these texts than is usual in contemporaneous authors, and larger text samples were selected in order to be sure they were representative for the author. 
Table 2. Corpus of text samples, listed in chronological order ${ }^{7}$

\begin{tabular}{|c|c|c|c|}
\hline Date & Author & Title & Text Type \\
\hline \multicolumn{4}{|l|}{ Period III } \\
\hline 1515 & Pedersen, Christiern & Jærtegns-Postil & $\begin{array}{l}\text { Bible paraphrase } \\
\text { and sermons }\end{array}$ \\
\hline 1529 & Pedersen, Christiern & Det nye Testamente & Bible translation \\
\hline 1531 & Pedersen, Christiern & $\begin{array}{l}\text { Om born ath holde till Scole } \\
\text { och Studium }\end{array}$ & treatise \\
\hline 1535 & Tausen, Hans & De fem Moseb $\phi$ ger & Bible translation \\
\hline 1539 & Tausen, Hans & Postil & sermons \\
\hline 1543 & Palladius, Peder & Visitatsbogen & speeches \\
\hline 1575 & Vedel, Anders Sørensen & Saxo: Den danske Kronike b & chronicle translation \\
\hline 1581 & Vedel, Anders Sørensen & $\begin{array}{l}\text { Om Den Danske kronickel } \\
\text { at bescriffue }\end{array}$ & history \\
\hline $1636-40$ & Chr. IV & Egenhandige Breve & letters \\
\hline 1638 & Brochmand, Jesper & Huspostil & sermons \\
\hline 1663 & Syv, Peder & Om det Cimbriske Sprog & treatise \\
\hline \multicolumn{4}{|c|}{ Period IV } \\
\hline $1732-35$ & Holberg, Ludvig & Dannemarks Riges Historie & history \\
\hline 1748 & Holberg, Ludvig & Epistler & epistles \\
\hline $1775-77$ & Sneedorff, J.S. & $\begin{array}{l}\text { Den patriotiske Tilskuer, Om } \\
\text { den Borgerlige Regiering }\end{array}$ & debate articles \\
\hline 1777 & Malling, Ove & $\begin{array}{l}\text { Store og Gode Handlinger af } \\
\text { Danske, Norske og Holstenere }\end{array}$ & moral stories \\
\hline \multicolumn{4}{|l|}{ Period V } \\
\hline $1816-19$ & Grundtvig, N.F.S. & Danne-Virke & philosophical \\
\hline $1824-38$ & $\begin{array}{l}\text { Grundtvig, N.F.S. } \\
\text { Grub } 6 \text { be deda } 5 \text {. }\end{array}$ & Prædikener & $\begin{array}{l}\text { treatises } \\
\text { sermons }\end{array}$ \\
\hline 1832 & Grundtvig, N.F.S. & Nordens Mythologi & $\begin{array}{l}\text { theological/ } \\
\text { philosophical treatise }\end{array}$ \\
\hline 1846 & Andersen, H.C. & Brevveksling Collin & letters \\
\hline $1835-72$ & Andersen, H.C. & Eventyr & tales \\
\hline 1855 & Kierkegaard, Søren & Øieblikket & debate articles \\
\hline 1866 & Petersen, N.M. & $\begin{array}{l}\text { Bidrag til den oldnordiske } \\
\text { Literaturs Historie }\end{array}$ & literary history \\
\hline 1871 & Brandes, Georg & $\begin{array}{l}\text { Hovedstromninger } i \text { det } 19 \text { de } \\
\text { Aarhundredes Litteratur }\end{array}$ & literary history \\
\hline $1875-76$ & Hørup, Viggo & I Skrift og Tale & political speeches \\
\hline $1889-90$ & Hørup, Viggo & Breve og Digte & letters \\
\hline \multicolumn{4}{|c|}{ Period VI } \\
\hline $1906-10$ & Brandes, Georg & Samlede Skrifter & literary history \\
\hline $1919-57$ & Henningsen, Poul & Kulturkritik & debate articles \\
\hline
\end{tabular}




\subsection{Delimiting the Variable: What should be counted?}

Having defined a data corpus, the next step is to determine what linguistic phenomena should be counted. Sociolinguistic diachronic studies have by and large proceeded as if the delimitation of the variable were not a particularly pertinent problem. ${ }^{8}$ In the literature on (synchronic) sociolinguistic variation, however, the case of syntactic variables has given rise to theoretical problems. Specifically, the demand for cognitive semantic equivalence between variants of the "same" variable creates difficulties (Milroy 1987:150ff), since very few of the potential syntactic variables we know of are completely semantically equivalent. Another way of putting this is that it is in the nature of language to exploit formal variation for semantic purposes. This is a familiar and fundamental tenet of all forms of functionalism: a given form is there to carry semantic content, hence the theoretical problem of synonymy at the lexical level and equivalence at the syntactic level. It follows that very few alternative syntactic constructions qualify, strictly speaking, as sociolinguistic variables.

A way out of this predicament has been elaborated by those who work with quantitative syntactic analyses of text corpora. Briefly, it holds that if a constant can be defined at a certain level having two or more variants at the next lower level, and if quantitative differences can be found in the use of the variants, then one has found a syntactic variable (Nedergaard Thomsen 1991: 338f).

This argument may be illustrated as follows. At the level of sentence types, we may define conditional clauses as a specific category characterized by stating the premises for a 'conclusion' which is asserted in the main clause. This definition is semantic and allows us to define syntactically two Danish variants. The first variant has a subordinating conjunction and SCWO. The clause may be preposed or not:

(7) Hvis han ikke var kommet, var jeg ikke gået

lit. If he not had come, had I not gone, i.e.: If he had not come I would not have gone

(8) Jeg var ikke gået, hvis han ikke var kommet

lit. I had not gone, if he not had come, i.e.: I would not have gone if he had not come

The other variant has no conjunction and has the word order of a question: the verb in first rather than second position, or an empty first position, according 
to the perspective chosen. This version, too, may be preposed or not:

(9) Var han ikke kommet, var jeg ikke gået

lit. Had he not come, had I not gone, i.e.: Had he not come, I would not have gone

(10) Jeg var ikke gået, var han ikke kommet

lit. I had not gone, had he not come

The conditional clause as a variable with four variants may in fact satisfy the criterion of semantic equivalence, although this is not essential.

Suppose now that we investigate the distribution of conditional clauses in a corpus which is stratified by the independent speaker variables of sex/ gender, age and class. We might find that there is a significant difference between, say, the sexes in the use of conditional clauses. The difference between the two approaches to defining the syntactic variable mentioned above would then be as follows:

In the first case, the result would be taken as another item on the long list substantiating gender determined differences in language, and that would be it: apparently, persons of one sex prefer one way of constructing their conditionals, and the other, another way.

In the second case, the onus would be upon the researcher to explain the difference textually: would it for instance be the case that within the data context chosen, women are more prone to pick from the list of possible speech styles certain modes which would trigger one construction rather than the other? In short, if there is no prior assumption of semantic equivalence, the various possible meanings of the construction must be investigated on the basis of the preliminary result proper. If no semantic explanation - such as linking the difference to higher linguistic levels, e.g. in terms of genre or text type - is forthcoming, then - and only then - will the difference be added to the long list of gender determined differences in language, themselves in need of further explanation. In the present study, we take the stance that statistical differences between social groups in the use of syntactic variants as such are uninteresting unless they can be explained in terms of such higher levels. So much for the theoretical preliminaries.

It remains to define what sentences among the thousands in the corpus are to be investigated. The point of departure is the difference between the SCWO and the MCWO. Recall that this is a question of the relative order of the Sentence Adverbials and the finite Verb. But a word order that is dependent on 
the presence of a sentence adverbial to be perceptually distinct from another word order is a feeble instrument for the identification of subordinate clauses, in that not all propositions are modified by sentence adverbials. Naturally, speakers must have more to go by. Hence, there must be other criteria for subordination than just the one we are investigating. We cannot scrutinize the effect of the relative order of the SA and the finite Verb, however, if there is no $\mathrm{SA}$ in the first place. We thus have to state as the most important requirement for a sentence to be included in the data set:

\section{The sentence must have a sentence adverbial.}

The second criterion is more tricky. If the defining criterion for a subordinate clause were that it has SCWO, then Danes would have had no subordinate clauses before they established this specific word order. This stance would leave no definition at the higher level possible. Luckily, as we have already noted, the definitions practiced by all grammarians have always had a more basic syntactic component:

A sentence which is a member of another sentence, or which is a relative clause, is a subordinate sentence (to the sentence whose member it is or the member of which is modified (by the relative clause)).

This definition was used to delimit the sentences actually used to count the variable in the present study.

A further - semantic - interpretation then makes possible a distribution of sentences among various subordinate clause types, e.g. causal, final, ${ }^{9}$ consecutive, concessive, nominal, and so on. A simple structural criterion for this classification focusing on which conjunction is introducing the subordinate clause will not do, since the conjunctions, and especially the central subordinating conjunction at (Eng. 'that'), in some of the historical periods introduce clauses which semantically can only be interpreted as final (modern Danish 'for at', i.e. 'in order to') or consecutive (modern Danish 'så at'). ${ }^{10}$ The subordinate clause types distinguished in this study are the following:

nominal that-clauses
final
interrogative
causal
temporal


comparative

concessive

conditional

consecutive

conjunctive

relative

Thus we focus on syntactically-defined subordinate clauses, and count for the various semantic types how many of them have subordinate word order (SCWO) and how many have main clause word order (MCWO).

\subsection{Results of the Analysis}

The results of this analysis can be charted as the percentage of clauses in each text sample having MCWO, as in Figure 1:

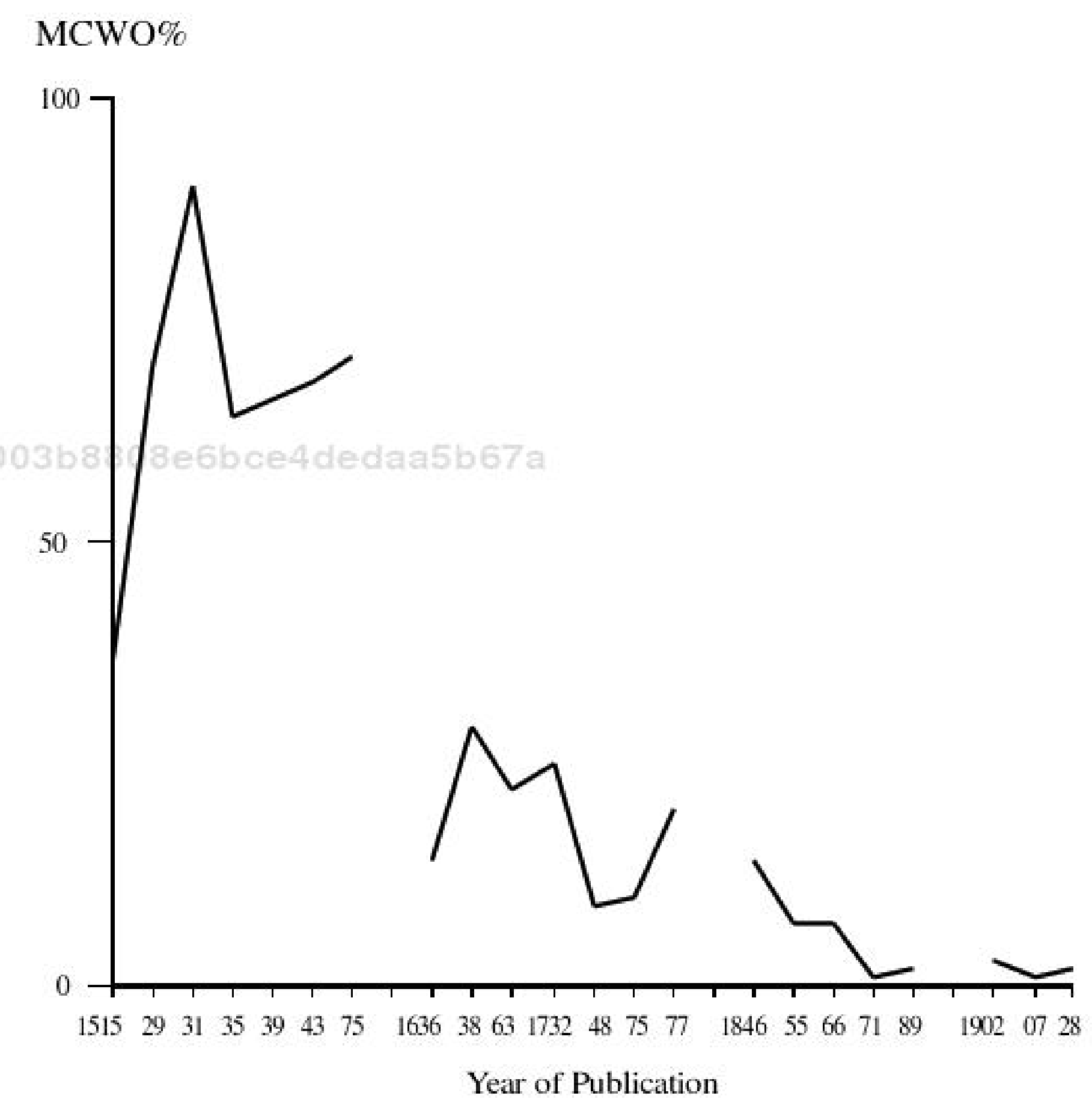

Figure 1. MCWO percentages for the texts in the corpus 
The trend is clear enough: gradually the MCWO loses ground to become very rare at the end of the period. The SCWO is almost exceptionless in subordinate clauses by 1900 .

From the beginning of this history, there seem to have been two types of word order in dependent clauses. The SCWO must have been introduced before the first excerpt, as witnessed by the fact that the first value for MCWO is only $37 \%$. Given that MCWO is the old word order, ${ }^{11}$ we have a terminus post quem: the SCWO must have been initiated at a point in time during what we call period II. Carl Larsson has documented the Danish and Swedish facts which seem to be quite parallel. He concludes that the change started in the beginning of the 14th Century (Larsson 1931: 145) with negated relatives as the first SCWO construction. The eminent historian of the Danish language, Skautrup, quotes Larsson's figures, contrasting a mere $1 \%$ of SCWO (that is, 99\% MCWO) in the oldest Danish law texts, with figures as high as $41 \%$ SCWO (59\% MCWO) in diplomas from 1403-1482 (Skautrup 1947:60f).

Larsson's observation suggests that it may also be instructive to consider the frequency of MCWO in different subordinate clause types. In Table 3, we have indicated which clause types are above the average Main Clause Word Order Percentage and which are below it. The order of mention of clause types reflects their relative deviation from the average (from most to least deviant) and the actual number of instances. If a clause type has only one or two instances, details are not given, as it is of no particular interest whether the figures go one way or the other. 
Table 3. Deviation from average MCWO by subordinate clause type

\begin{tabular}{|c|c|c|c|c|}
\hline Date & Author & Avg. & Above avg. & Below avg. \\
\hline \multicolumn{5}{|c|}{ Period III } \\
\hline 1515 & Pedersen, Christiern & $37 \%$ & nominal that & relative \\
\hline 1529 & Pedersen, Christiern & $70 \%$ & nominal that & relative; consecutive \\
\hline 1531 & Pedersen, Christiern & $90 \%$ & causal; final & $\begin{array}{l}\text { relative; nominal } \\
\text { that }\end{array}$ \\
\hline 1535 & Tausen, Hans & $64 \%$ & $\begin{array}{l}\text { temporal; nominal } \\
\text { that; causal }\end{array}$ & $\begin{array}{l}\text { conditional; relative; } \\
\text { final }\end{array}$ \\
\hline 1539 & Tausen, Hans & $66 \%$ & $\begin{array}{l}\text { consecutive; causal } \\
2 \uparrow 086 \uparrow 20003 b 8:\end{array}$ & $\begin{array}{l}\text { relative; nominal } \\
\text { that; conditional; } \\
\text { comparative dedaa } 5 \text { b } 67 \text { a }\end{array}$ \\
\hline 1543 & Palladius, Peder & $68 \%$ & $\begin{array}{l}\text { causal; consecutive; } \\
\text { nominal that }\end{array}$ & conditional; relative; brary \\
\hline 1575 & Vedel, Anders Sørensen ${ }^{12}$ & $71 \%$ & - & \\
\hline 1636 & Chr. IV & $14 \%$ & temporal; consecutive & causal; relative \\
\hline 1638 & Brochmand, Jesper & $29 \%$ & $\begin{array}{l}\text { causal; consecutive; } \\
\text { conditional; nomi- } \\
\text { nal that } \\
\text { causal; concessive; } \\
\text { nominal that }\end{array}$ & $\begin{array}{l}\text { interrogative and } \\
\text { concessive }=0 ; \\
\text { relative; temporal } \\
\text { conditional and } \\
\text { consecutive }=0 ; \\
\text { relative }\end{array}$ \\
\hline \multicolumn{5}{|c|}{ Period IV } \\
\hline $1732-35$ & Holberg, Ludvig & $25 \%$ & nominal that & $\begin{array}{l}\text { causal, interroga- } \\
\text { tive and relative }=0\end{array}$ \\
\hline 1748 & Holberg, Ludvig & $9 \%$ & $\begin{array}{l}\text { consecutive; } \\
\text { nominal that }\end{array}$ & $\begin{array}{l}\text { interrogative and } \\
\text { causal }=0 \text {; relative }\end{array}$ \\
\hline $1775-77$ & Sneedorff, J.S. & $10 \%$ & conditional & causal, concessive \\
\hline $2 c 003 b$ & 8808 e 6 bce 4 dedaa 5 b 6 & $7 a$ & & $\begin{array}{l}\text { and temporal =0; } \\
\text { relative }\end{array}$ \\
\hline 1777 & Malling, Ove & $20 \%$ & interrogative; causal & $\begin{array}{l}\text { consecutive, relative } \\
\text { and temporal }=0 ; \\
\text { nominal } \text { that }\end{array}$ \\
\hline \multicolumn{5}{|c|}{ Period V } \\
\hline 1816 & Grundtvig, N.F.S. & $16 \%$ & nominal that & $\begin{array}{l}\text { causal, concessive, } \\
\text { consecutive }=0\end{array}$ \\
\hline 1819 & Grundtvig, N.F.S. & $17 \%$ & $\begin{array}{l}\text { consecutive; nominal } \\
\text { that; interrogative }\end{array}$ & $\begin{array}{l}\text { causal, conditional, } \\
\text { concessive }=0\end{array}$ \\
\hline 1824 & Grundtvig, N.F.S. & $39 \%$ & $\begin{array}{l}\text { nominal that; final; } \\
\text { consecutive }\end{array}$ & $\begin{array}{l}\text { conditional, } \\
\text { interrogative }=0\end{array}$ \\
\hline 1832 & Grundtvig, N.F.S. & $29 \%$ & $\begin{array}{l}\text { consecutive; nominal } \\
\text { that }\end{array}$ & $\begin{array}{l}\text { comparative, } \\
\text { concessive, } \\
\text { conditional }=0\end{array}$ \\
\hline 1846 & Andersen, H.C. & $14 \%$ & $\begin{array}{l}\text { (only instances with } \mathrm{N} \\
\text { nominal that, } 1 \text { interrc } \\
15 \text { relative) }\end{array}$ & $\begin{array}{l}\text { MCWO: } 4 \text { out of } 31 \\
\text { ggative and } 1 \text { out of }\end{array}$ \\
\hline
\end{tabular}




\begin{tabular}{|c|c|c|c|}
\hline 1855 & Kierkegaard, Søren & $7 \%$ & $\begin{array}{l}\text { (only instances with MCWO: } 1 \text { nominal } \\
\text { that } 11 \text { causal) }\end{array}$ \\
\hline $1835-72$ & Andersen, H.C. & $20 \%$ & $\begin{array}{ll}\text { consecutive; nominal } & \begin{array}{l}\text { all but relative and } \\
\text { that }\end{array} \\
\text { temporal }=0\end{array}$ \\
\hline 1866 & Petersen, N.M. & $7 \%$ & $\begin{array}{l}\text { (only instances with MCWO: } 5 \text { out of } 25 \\
\text { nominal that; } 1 \text { out of } 11 \text { consecutive) }\end{array}$ \\
\hline 1871 & Brandes, Georg & $1 \%$ & (only 1 example) \\
\hline $1875-76$ & Hørup, Viggo & $3 \%$ & (3 examples) \\
\hline $1889-90$ & Hørup, Viggo & $2 \%$ & ( 2 examples) \\
\hline \multicolumn{4}{|c|}{ Period VI } \\
\hline 1906-10 & Brandes, Georg & $1 \%$ & (only 1 example) \\
\hline $1919-57$ & Henningsen, Poul & $2 \%$ & ( 2 examples) 003 b8808e6bce 4 ded \\
\hline
\end{tabular}

Table 3 shows that that-clauses tend historically to favor MCWO, while SCWO is favored by relative clauses and conditional clauses, although there are exceptions to both trends. Causal clauses, on the other hand, appear to favor each order equally. As we demonstrate in section 3 below, the MCWO is found in modern spoken Danish overwhelmingly in just two clause types, viz. the causal and the nominal that-clauses. Conversely, relative clauses and conditional clauses invariably do not take the MCWO in our material from Copenhagen. The distribution of the two word orders in modern spoken Danish can thus be seen as the remnants of a historically older pattern.

That-clauses are consistently above or at the average in the majority of excerpts. Since at the end of the period there are very few instances of MCWO, this generalization is potentially significant and points to the special status of nominal that-clauses.

Moreover, the chronology of the change from MCWO to SCWO may not be independent of text type. This can be seen from an inspection of the three earliest texts which originate with the same author. Traditionally, Christiern Pedersen is credited with being the creator of the first consistent orthographical norm for Danish (Skautrup 1947:187). He was a prolific writer and editor who vigorously put the printing press to use in his tireless efforts to enlighten the populace religiously. The three texts by Pedersen in the sample were among the first religious texts to be read by the Danish people (Friis 193745[1975]:213). The 1519 text is based on Latin sources, while the 1529 and 1531 texts rely on German sources. ${ }^{13}$

The first percentage in Figure 1 is from Pedersen's Jartegns postil, a collection of (paraphrasing) translations of the evangelical and epistle lessons 
from the Sunday masses with commentaries and interpretations. The second entry is the same author's translation of The New Testament, and this manifests quite different percentages of MCWO. The third entry is an excerpt from a treatise on the proper schooling of children, which is an 'original translation', in that it is based on a treatise by Luther on the subject. The figures for the three texts vary from $37 \%$ to $90 \%$, a considerable difference which in itself raises doubts as to the independence of subordination and the text type taken as data. Why the figures vary is harder to explain, but by far the largest portion of the syntactically subordinate sentences are that-clauses.

The figures for the that-clauses in the three Pedersen texts vary from $45 \%$ to $90 \%$, and interestingly do not co-vary completely with the aggregated figures: the highest figure of $90 \%$ is for the that-clauses from the 1529 translation of The New Testament, not from the 1531 treatise on schooling children. An instructive graphical representation may be had if we concentrate on the that-clauses, as shown in Figure 2:

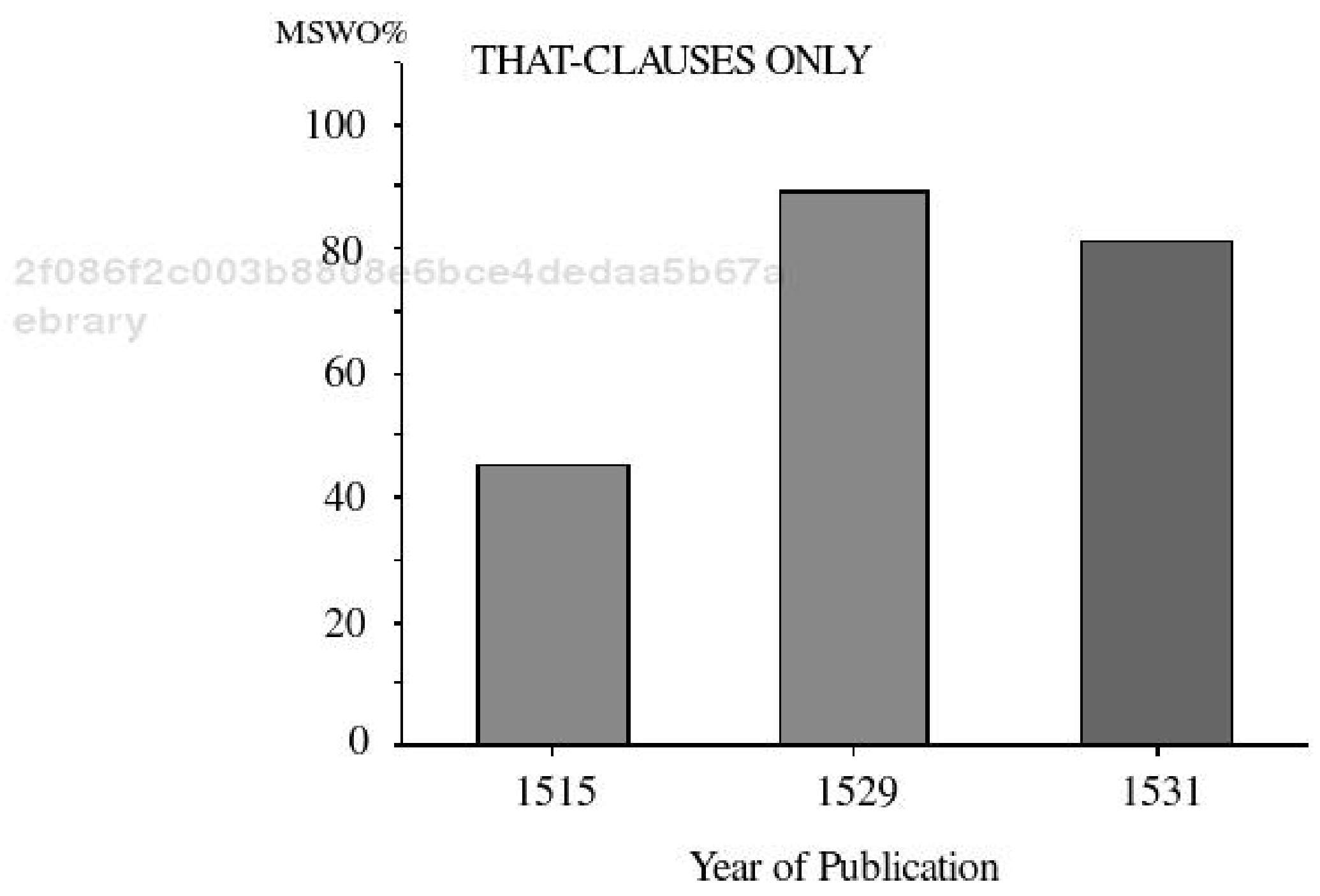

Figure 2. MCWO percentages for nominal that-clauses in three texts by Chr. Pedersen 
One possible explanation for these results is that main clause word order in that-clauses may indicate direct quotation when the primary sentence taking the that-clause as its complement features a verb of saying or telling. The MCWO would thus be more frequent in text types with a large amount of reported speech, such as the scriptures. However, this characterization is not sufficiently precise, because all the texts excerpted are concerned with recounting the testament directly or indirectly. We must add that the use of the main clause word order may be seen as an optional stylistic device which dramatizes the story, as it were, by recounting the words as spoken. An explanation for the high figures for the translation of the New Testament might accordingly be that $\mathrm{Chr}$. Pedersen preferred to use this means of dramatization in this particular text.

That-clauses often function as objects of verbs of saying or telling, and in these cases often have the MCWO. The following examples show how this works:

\section{From: Chr. P.: Det Nye Testamente}

Danske Skrifter III (v/ Brandt \& Fenger, Kbh. 1852)

Apostlenes Gerninger, 1.-15. kapitel (incl.) p. 222-255

222 Han kallede dem sammen och bødh dem ath de skulle icke gaa aff Iherusalem Translation: He assembled them and commanded them not to go from Jerusalem (lit.: that they should not go (with MCWO, cf. SCWO: that they not should go))

224 I skulle alle vide ath disse mend ere icke drukne som i mene Translation: You should all of you know that these men are not drunk as you think (lit.: that these men are not (with MCWO, cf. SCWO: that these men not are))

229 Saa kallede de dem ind igen oc forbøde dem strengelige ath de skulle icke tale eller lare $\mathrm{i}$ Thesu naffn Translation: Then they called them in again and forbade them harshly to speak or teach in the name of Jesus (lit.: that they should not talk or teach)

Chr. P.: Om børn ath holde till Scole och Studium...

Danske Skrifter IV (v/ Brandt og Fenger. Kbh. 1854) p. $510-518$

510 Der ere vel mange som skulle sacte sige/ at det gøris icke behoff at lade børn lære forneffnde konster och twngemaal Translation: There are presumably many who would say that it is not necessary that children learn the aforementioned arts and languages (with MCWO)

This method of dramatization imitates speech in the written mode by changing the word order. It does not, however, explain away all the main clause word orders. We find subordinate clauses with causal and consecutive content also having main clause word order: 
514 Denne store skade och forsømelse er skeet fordi Ath mand hagde icke gode gamble bøger ath lære oc fonge ret fwndamente vadff Translation: This great damage and neglect has happened because one did not have good old books to learn and get the fundament from (lit.: man had not good old books cf. SCWO: man not had)

517 Oc huorledis de skulle tiene Gud deries herre/ (...) Ath de mwe siden bliffue salige och leffue meth hannem Translation: And how they should serve God their Lord (...) so that they may since be blessed and live with him (cf. SCWO: so that they since may be blessed)

These examples suggest that the MCWO has its stronghold in clauses which report utterances, with the conjunction in such cases functioning like a modern colon, but that it is by no means confined to this use exclusively.

A particularly instructive comparison is the following almost identical pair of sentences, the first having the SCWO, the second having the MCWO. Apparently the word order was indeed variable, and for us at least there is no cognitive semantic effect (obviously, we cannot be certain what contemporaries thought), only a stylistic difference. Yet we note that the MCWO is used with the present tense and the adverb 'strax' ('at once'), that is, in the clause which conveys the greater sense of immediacy:

Chr. P.: Jærtegns Postil

Danske Skrifter II,1 (v/ Brandt \& Fenger, Kbh. 1851)

Hellig trefoldigheds søndag ff

111 Thii de rædiss at de aldrig skulle fonge nock

Since they become afraid that they would never get enough (lit. that they never should (with SCWO))

11103 da rædiss hun strax at hun skall icke fonge nock aff iorden at æde

Then at once she becomes afraid that she will not get enough from the earth to eat (lit. that she shall not (with MCWO))

If we abstract from the variation in percentages related to text types, the direction of the change is clear: it goes from the figure of $90 \%$ at the beginning, to figures close to nil at the end of the period, thus seemingly substantiating the claim made by Wivel and later grammarians that a defining feature of subordinate clauses is subordinate word order. If we narrow the focus and count only the MCWO's in that-clauses, we get a more refined instrument with which to measure the development towards exclusive subordinate word order, one which, however, still shows the same overall trend. The MCWO percentages in that-clauses only are given in Table 4: 
Table 4. MCWO percentages in that-clauses in texts ordered chronologically

\begin{tabular}{|c|c|c|c|}
\hline Author & Text & Date & MCWO\% \\
\hline Christiern Pedersen & Jærtegns-Postil & 1515 & 45 \\
\hline Christiern Pedersen & Ny Testamente & 1529 & 89 \\
\hline Christiern Pedersen & Børn ath holde till scole & 1531 & 81 \\
\hline Hans Tausen & De fem Mosebøger & 1535 & 63 \\
\hline Hans Tausen & Postil & 1539 & 42 \\
\hline Peder Palladius & Visitatsbog & 1543 & 78 \\
\hline Anders Sørensen Vedel & Saxotranslation & 1575 & 79 \\
\hline Anders Sørensen Vedel & Krønike & 1581 & 83 \\
\hline Chr.IV & Breve & 1636 & 14 \\
\hline Jesper Brochmand & Huspostil $\quad 2 f 086 f 200$ & $1638808 e 6 b$ & 29 dedaa: \\
\hline Peder Syv & Om det Cimbriske Sprog & 1663 & 42 \\
\hline Holberg & Dannemarks Riges Historie & $1732-35$ & 38 \\
\hline Holberg & Epistler & 1748 & 14 \\
\hline Sneedorff & Den Patriotiske Tilskuer mm & $1775-77$ & 12 \\
\hline Malling & Store og Gode Handlinger & 1777 & 18 \\
\hline Grundtvig & Danne-Virke & 1816 & 34 \\
\hline Grundtvig & Danne-Virke & 1819 & 22 \\
\hline Grundtvig & Prædikener & $1824-25$ & 64 \\
\hline Grundtvig & Nordens Mythologi & 1832 & 49 \\
\hline Andersen & Eventyr & $1835-72$ & 22 \\
\hline Andersen & Breve & 1846 & 11 \\
\hline Kierkegaard & Øieblikket & 1855 & 7 \\
\hline \multirow[t]{2}{*}{ N.M.Petersen } & Bidrag til den oldnordiske & & \\
\hline & Literaturs Historie & 1866 & $20^{14}$ \\
\hline Brandes & Hovedstrømninger & 1871 & 0 \\
\hline Hørup & I Skrift og Tale & $1875-76$ & 2 \\
\hline Hørup $3 b 8808 e 6 b c e 4 c$ & Breve $677^{a}$ & $1889-90$ & 0 \\
\hline Brandes & Samlede Skrifter & $1906-10$ & 6 \\
\hline Poul Henningsen & Kulturkritik & $1919-57$ & 8 \\
\hline
\end{tabular}

The evolution of the SCWO may be summarized as follows: the SCWO developed in period II before the analysis documented here takes its point of departure (cf. above). We have documented a long, more or less gradual, development since period III from a system with solely syntactic means of expressing subordination - i.e. by using conjunctions and the valency of the matrix verb, and with the word order of the subordinate clause having only stylistic value - to a system with more weight on topology as the central means of expression. At the end of the periods documented, viz. at the beginning of this century, the MCWO is almost never found in a subordinate clause in the central documents of written Danish prose. This means that the 
topological feature of word order in the subordinate clause has now become grammaticalized and may be used by grammarians as a formal means of distinguishing the subordinate clause from the main clause.

At the same time as the direction of the change remains clear, the evolution seems to be uneven, with the father of Danish prose and drama writing, Ludvig Holberg, varying between $38 \%$ and $14 \%$ depending on the text genre. Holberg in this as in many other respects is a sort of transitional figure hovering between the past and the future: he shows that he knows how to use the construction to create stylistic variation, but it is not central for his prose. The figures seem to turn in the 17th century. One text from this period, viz. Chr.V's Danske Lov, the central legislative compilation from 1683, presents a further complication in that its subordinate clauses very often have a verb-final construction, undoubtedly due to German influence, which renders the dichotomy between SCWO and MCWO meaningless. ${ }^{15}$ Thus there was a triad of possibilities for the construction of subordinate clauses in Danish in this period of transition.

Grundtvig (1783-1872) is the grand exception to any rule of Danish prose construction, and this case is true to form. The tendency for main clause word order to disappear is simply not valid for his prose. Since he is writing at a time when other authors (like H.C. Andersen and N.M. Petersen) have figures clustering around $20 \%$ for MCWO in that-clauses, and Søren Kierkegaard, for example, has figures which are considerably lower than that, it is not strange that his peculiar style was noted by his contemporaries. What is interesting is what impression it made. In one of the school books from the period, the author notes that "Sometimes (in particular common with some authors) the negation in a subordinate clause follows the verb" and proceeds to give an example from Grundtvig (Broby 1867:59). ${ }^{16}$ The MCWO in subordinate clauses has by this time become so rare as to be seen as a feature characteristic of specific authors' - in this case Grundtvig's - style.

Grundtvig's prose style was often rated as 'popular' as was Andersen's. The reason may very well have been that both renewed the Danish prose style by incorporating features from the spoken language. And by this time the MCWO would have been characteristic of the spoken language: seeing that the MCWO survived for a long time in the dialects (cf. section 4 below) and has remained to this very day in the two sentence types isolated in section 3 below, it may well be the case that the MCWO was the dominant or only word order in the spoken language all through this period and thus could be 
imported whenever an author wished to avoid the predominantly latinized written style.

Here we come to a crux of much diachronic speculation: how is it possible to reconstruct an account of the spoken language when all that is left are written documents? We seem throughout the documented historical past to witness a development of progressing autonomy for the written language: written texts develop their own standards of correctness, their own complexity as opposed to that of spoken language. All the same, we fervently wish to be able to catch a glimpse of the history of the spoken language.

One indirect means of doing this is to connect the distant past with the present by examining the data of sociolinguistic investigations of contemporary spoken language in relation to written data from the periods before the autonomy of writing was firmly established. Another is to look at spoken data from traditional rural dialects. Since some dialects are more conservative than others and rural dialects have been less influenced by the standardization process than has the written language, they might be able to tell us something about an earlier stage of Danish. In the following sections, we report on an attempt to apply both of these methods to the phenomenon of word order variation in subordinate clauses.

\section{MCWO in the Speech of 31 Native Copenhageners}

The Copenhagen Study in Urban Sociolinguistics (Gregersen and Pedersen 1990, Gregersen and Pedersen 1991, Gregersen 1995, Pedersen 1995) investigated the speech of a sample of native Copenhageners using a modified version of the field methods of William Labov (Labov 1984) and Lesley Milroy (Milroy 1980). We collected sociolinguistic interviews with more than 40 informants, all of them born and bred in Copenhagen. The interviews were transcribed using standard Danish orthography with additional notations for pauses and hesitation, etc.

In order to investigate the use of the MCWO in syntactically subordinate clauses (i.e. sentences which are either members of other sentences or relative clauses) in spoken Danish, we put together a sample from the larger corpus of transcripts. The informants belong to two sexes, two age groups (I:15-24 years of age, IIa:25-40 years of age) and two social classes (Working Class=WC, Middle Class=MC). We refer the reader to Gregersen and Pedersen (1991) for 
further information on how class was defined and why these particular age groups were selected.

Table 5. Distribution of informants from the Copenhagen Study

\begin{tabular}{|c|c|c|c|c|c|c|c|}
\hline \multicolumn{2}{|c|}{$\begin{array}{l}\text { Working Class } \\
\text { Age Group I }\end{array}$} & \multicolumn{2}{|c|}{$\begin{array}{l}\text { Middle Class } \\
\text { Age Group I }\end{array}$} & \multicolumn{2}{|c|}{$\begin{array}{l}\text { Working Class } \\
\text { Age group IIa }\end{array}$} & \multicolumn{2}{|c|}{$\begin{array}{l}\text { Middle Class } \\
\text { Age group IIa }\end{array}$} \\
\hline$\overline{\text { Females }}$ & Males & Females & Males & Females & Males & Females & Males \\
\hline 3 & 2 & 4 & 2 & 8 & 5 & 5 & 2 \\
\hline
\end{tabular}

The total number of informants is 31 , although the only cells with enough tokens to be representative are those of the females - except the WC age group I - and the males of the WC group IIa. ${ }^{17}$

Since negation is universally the most frequent sentence adverbial, we searched in the files for the negation ikke. This initially turned up many primary clauses which had to be discarded. The result of the cleansing process is a sample consisting of 637 subordinate clauses with sentence adverbials, overwhelmingly the most frequent being ikke.

Of the subordinate clauses, $222(35 \%)$ have MCWO. The means of subordinate clauses with MCWO for each informant group are given in Table 6 :

Table 6. Group means for the number of subordinate clauses with MCWO

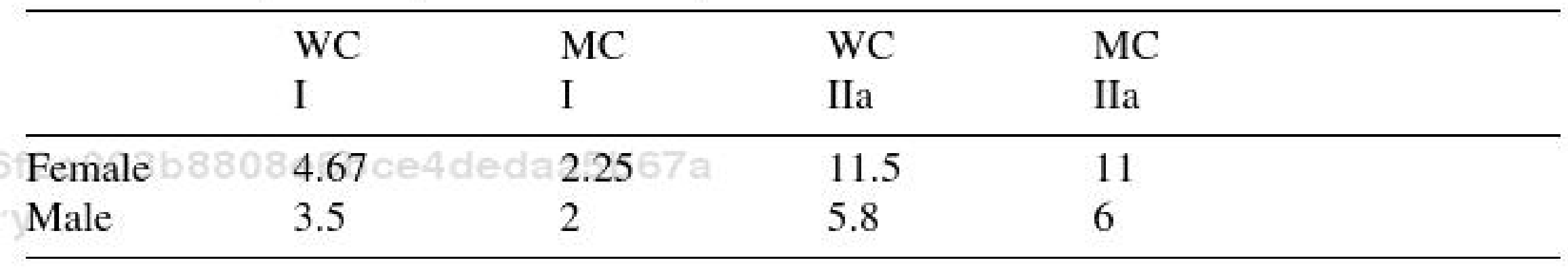

These figures are suggestive: it seems to be the case that the well-documented groups of IIa women have significantly higher means than the rest of the groups, including the equally well-documented group of IIa WC men. It thus appears that women use MCWO more than men. Since in section 2 above we adopted the convention that statistical differences would have to make sense by being linked to higher linguistic levels, we would have to come up with a good reason for these two particular groups of women to use the MCWO significantly more than other groups, presumably by looking for dramatization in the form of narratives in the interviews (cf. Møller 1991, 1993). We have not done this for the simple reason that the result as it stands merits a 
deeper analysis: what clause types manifest the MCWO?

An investigation of the pattern of clause types in the material proved to be easy: the sample contains three concessive clauses, one conditional clause and one consecutive clause with MCWO. All the rest of the subordinate clauses with the MCWO are that-clauses and causal clauses introduced by fordi (Eng. 'because').

To document the use of MCWO in the most common clause types, we report both raw numbers and percentages for three clause types: that-clauses with and without an explicit conjunction, and causal clauses with fordi.

\section{Subordinate that-clauses}

Of a total of 197 that-clauses, 77 have the MCWO, corresponding to $39 \%$. Some of the that-clauses have an explicit at, some do not. The clauses without an explicit at have a higher MCWO\% (45\%) than those with an explicit conjunction (which are at 36\%). It should be noted that only the basic syntactic criterion is valid when neither the conjunction nor the word order signals subordination. The distribution of MCWO in that-clauses according to speaker variables is shown in Table 7 .

Table 7. Groupwise distribution of $M C W O$ percentages for all that clauses

\begin{tabular}{lll}
\hline AGE GROUP/CLASS & WC & MC \\
\hline Age group I, female & 50 & 25 \\
Age group I, men & 33 & 67 \\
Age group IIa, female & 46 & 42 \\
Age group IIa, men & 33 & 25 \\
\hline
\end{tabular}

Four groups stand out in this table as having comparatively high MCWO figures: the girls of the WC, the boys of the MC (but note that there are only two of them) and the two adult female groups. A reasonable description of what these four groups may have in common escapes us. Neither in terms of higher levels (narratives), nor in terms of social class or gender distinctions does the variable make sense. Just to mention one simple point: Møller (1993: 136) shows that the number of narratives told in the Copenhagen interviews significantly distinguishes the WC IIa women from their MC age mates (the WC women having a significantly higher number of narratives per 100 minutes). 


\section{Subordinate causal clauses}

Out of a total of 168 causal clauses, 140 , or $83 \%$, have the MCWO. Thus the majority of the causal subordinate clauses introduced by the conjunction fordi (Eng. 'because') have the MCWO, and furthermore, the majority of the 222 subordinate clauses with the MCWO are causal. The distribution of MCWO according to speaker variables in causal clauses with fordi is shown in Table 8 below.

Table 8. Groupwise distribution of MCWO percentages for all causal clauses with FORDI

\begin{tabular}{llr}
\hline AGE GROUP/CLASS & WC & MC \\
\hline Age group I, female & 91 & 63 \\
Age group I, men & 80 & 100 \\
Age group IIa, female & 69 & 92 \\
Age group IIa, men & 95 & 67 \\
\hline
\end{tabular}

Here we have a rather different pattern: the $\mathrm{MCWO}$ is relatively higher for the WC girls and the MC boys, as in Table 7 above, but in age group IIa, the MC females pattern together with the WC men. Looked at from the class angle, the only generalization is that the various cells do indeed diverge, although in contrasting directions. This means that the class groups as such are heterogeneous. Nor does the gender perspective help us: the cross-over pattern is uninterpretable.

Thus the informants in the Copenhagen sample apparently have variable word order in that-clauses, whereas a fair number of them (13 of the 31$)$ use fordi as a conjunction which is on a par with any other coordinating conjunction such as 'and' or 'but', which means that it is categorically followed by MCWO. The rest of the informants treat fordi and at as conjunctions which may introduce clauses with either MCWO or SCWO.

The frequency of the MCWO in subordinate clauses in the spoken Modern Danish of these Copenhageners, compared with the evidence of the diachronic study, tells us that the MCWO is still present in the spoken language. It does not seem to be a sociolinguistic variable in the sense of being typical of any group delimited by the speaker variables of social class, age and gender. On the other hand, it is obviously a variable in that it varies. This creates a situation which is open for various historical interpretations: is the MCWO in modern spoken Danish a relic of the old order, or can it be explained in other ways? Why has it ended up being characteristic of only two 
clause types, and why these two? A look at the dialect evidence might be helpful before proceeding to the conclusion.

\section{The Dialect Evidence}

Since rural dialects are often more conservative than the standard language, data from such dialects might add to the picture of how things were in the past. Pedersen (1996) reports on a search of the files at the Institute of Danish Dialect Research for subordinate clauses using a computer program called Word Cruncher. The results of this study can be summarized as follows.

The four principal regions of Denmark are included in the corpus: Jutland, Funen, Zealand, and Bornholm. Bornholm and Jutland used to be isolated regions, and they are known to be more linguistically conservative than Zealand, which is the more urbanized region, including the metropolitan area of Copenhagen which forms the heartland of the Danish standard language. The geographical distribution of MCWO in the four regions is given in Table 9 (Pedersen 1996:243):

Table 9. Regional distribution of MCWO percentages

\begin{tabular}{lcccc}
\hline clause type & Region:Jutland & Region:Funen & Region:Zealand & Region:Bornholm \\
\hline nominal that & 72 & 69 & 58 & 9 \\
final & 50 & - & 0 & - \\
mixed $^{18}$ & 86 & 0 & - & - \\
interrogative $_{\text {causal }}$ & 50 & 0 & 0 & 0 \\
conditional & 73 & 100 & 60 & 0 \\
consecutive & 0 & 8 & 0 & 0 \\
relative & 76 & 69 & 55 & 38 \\
temporal & 26 & 50 & 0 & 0 \\
total no. of & & 7 & 11 & 0 \\
$\quad$ clauses & 109 & 50 & 18 & 10 \\
total MCWO $\%$ & $\mathbf{5 5}$ & $\mathbf{4 2}$ & $\mathbf{2 3}$ & $\mathbf{1 5}$ \\
\hline
\end{tabular}

From a geographical point of view, Jutland - furthest to the west of Copenhagen - has high numbers for all types except the conditional and the temporal, while the figures trail off to a comparatively low MCWO percentage for Bornholm to the east of Copenhagen. ${ }^{19}$ As in Copenhagen, the thatclauses and the causal clauses are high on the list for all regions except 
Bornholm, with the consecutive type not far behind.

The dialect survey also shows an alternative construction that tends to blur the simple dichotomy of MCWO versus SCWO. This is the phenomenon of neg-attraction to the conjunction: the negation can be moved to the position immediately adjacent to the conjunction, thus forming a composite conjunction, as in (11):

(11) han var glad for at itte (ikke) der var blevet toldet af hans sæed lit. He was glad for that not there had been charged of his seed He was happy that they had not charged money from his seed

This particular construction has its stronghold on Zealand (half of the negated sentences of the corpus) but may be found all over Denmark. It is an alternative way of signalling subordination without any connotations of written language, and by its mere existence, it blurs the dichotomy.

In general, the figures of the dialect survey correspond to the assumption that MCWO is an archaic feature of spoken language: MCWO is much more common in the conservative Jutland dialects than on Zealand, and the Jutland dialects also have MCWO in the largest number of clause types.

\section{Conclusion}

In this chapter, we have documented that the SCWO gradually evolved to become specialized as typical and even a defining characteristic of subordinate clauses in written Danish, and that as a consequence, the MCWO became characteristic of primary clauses. This development split the written norm from the spoken language, in that the SCWO became close to obligatory in the written language beginning in the early 19th century. In contrast, causal clauses and nominal that-clauses both still have the MCWO in the spoken language, with the MCWO being almost categorical for causal clauses.

The descriptive apparatus necessary to cope with this state of affairs may be had from Lars-Gunnar Andersson's analysis of subordination. He concludes:

A syntactically subordinate clause is a clause that is introduced by a complementizer.

A syntactically main clause is a clause that is not introduced by a complementizer. 
A semantically subordinate clause is a clause that does not make a statement, ask a question or give a command.

A semantically main clause is a clause that makes a statement, asks a question or gives a command. (Andersson 1975:217)

With this as a point of departure, the development of written Danish can be sketched as an evolution towards the exploitation of word order to signal the semantic difference between subordinate and main clauses, thus making it possible in some cases to have sentences which omit the otherwise syntactically decisive complementizer. In this way, the semantic difference gets expressed by other means (i.e. by means other than syntax in Andersson's sense).

On the other hand, as already noted above, the signal is comparatively feeble given that not all subordinate clauses include a sentence adverbial. A comparison of Danish with other Germanic languages makes it necessary to introduce a distinction between feeble and strong signals for subordination. A strong signal is a construction that is obligatory for all subordinate clauses, whereas a feeble signal is a construction which does not obligatorily appear. A strong signal thus has to do with the verb, since this is the only category which historically is obligatory in all sentences, cf. the historical possibility of subjectless sentences. Among the Germanic languages, German has chosen to use a strong signal of subordination in the form of the verb-final construction, whereas the Scandinavian languages, i.e. Modern Norwegian, Swedish and Danish, have by and large chosen the feeble signal described above.

According to von Polenz (1978: 95), the German grammarians taught the verb-final construction from the 16th century, and the strong signal was an option for a period in both Swedish and in Danish as well, although it is our impression that it was a vital option for much longer in Swedish than in Danish (cf. Pettersson 1988). ${ }^{20}$ English and Icelandic, in contrast, settle solely for the complementizer option, with no word order signals at all (i.e. all clauses have MCWO, whether subordinate or not). This is a reminder to those researchers who might think that the development was inescapable and has to do with the influence of writing: it is not necessary to signal subordination by any means other than the complementizer, and even that may be left out, in which case only the valency of the verb functions as an indicator.

This, then, is the picture that emerges for the written languages. Spoken Danish, in contrast, seems to have the possibility of signalling more complex 
categories than just independent and dependent clauses. In addition to the normal situation where the semantic and the syntactic criteria agree, whether this be in expressing subordination or primary status, we may theoretically posit two complex situations: one where the semantics points towards subordination (i.e. no question is asked, no statement made nor any command given) but the syntax says primary clause (no complementizer), and another where the semantics says primary whereas the syntax says subordinate clause. One way to manifest a syntactically subordinate but semantically primary clause would be MCWO. This predicts that there could be a semantic difference between a subordinate clause with the SCWO and a subordinate clause with the MCWO, inconsistent with the requirement of semantic equivalence for variants of a single syntactic variable. The MCWO would thus have grammaticalized in spoken Danish as a separate means of expressing a new complex clause category. Indeed, the Danish grammarian Lars Heltoft (1986) has suggested that this is precisely the case in Modern Danish.

Grammaticalization is a process, and a process cannot be documented with certainty before it has reached its completion. When it is completed, the clauses which manifest the grammaticalized feature will be interpreted as different from the clauses which lack it - and consistently so. When the process is still ongoing, however, we may not be certain whether a particular feature is (developing into) a grammatical marker or is a regular sociolinguistic variable. Since in this particular case we do not see a consistent semantic difference which would be a sign of completed grammaticalization, we must still treat the question as unanswered for word order in modern spoken Danish subordinate clauses. It is to be noted, however, that the results of professor Peter Auer's analysis of authentic dialogue material point to exactly the same grammaticalization process ongoing in modern German. ${ }^{21}$

This evidently raises the question of a particular construction's status in the description of a language. We have shown that the Danish written standard language has completed the grammaticalization of the SCWO and suggested that the spoken language has not (yet?) grammaticalized the MCWO in a much more restricted function. If this is indeed the case, spoken and written modern Danish cannot be described as one language in this respect; rather Danish must be separated into its two distinct modes.

We are left to account for the evolution and ultimate victory of the SCWO. The facts presented lend themselves to several types of explanation. One may be called 'the national history of language' framework. With the rise 
of the nation state in Europe, linguistics had to deal with the problem of construing an object which was simultaneously part of a family of languages, and a cultural object distinct from all other languages. Since the various spoken forms of the languages of Europe shade imperceptibly into one another, i.e. form a dialect continuum, the second objective could only be reached by construing maximally distinct written languages. The relationship between the standard languages and the nation states in which they were used varied considerably. In the Nordic countries, however, the standard languages of Danish and Swedish were established as the emblem of the nation and as the embodiment of the spirit of the people by the so-called romantic school of linguistics (notably N.M. Petersen). ${ }^{22}$

This had two consequences. The first was that the dialects were gradually reduced to (rural) forms of speech; the nation state had to have only one written language, the standard language. This development had already started with the advent of the printing press, when readers had became accustomed to seeing a more or less uniform written form of Danish. But with the gradual expansion of the teaching of reading and writing in the beginning of the 19th century, the writing pupil in e.g. Jutland had to be taught to write the standard language, although this meant that his speech could not be represented in his writing in the same way as before. His Jutland forefathers were identifiable as such simply because their speech was evident in their writings. This process may be called internal colonization or the linguistic uniformization of the nation.

The second consequence was ideological. From the beginning of the 19th century, all discussion of language was historical and predicated upon the existence of distinctive languages. However, the actual fact of the speech communities in Europe was that no significant linguistic border was evident at the frontiers of the nation states. Therefore, linguists had to construct a 'history of the language' (Crowley 1989) for each written standard, tracing it back to its earliest manifestations. This meant that all developments were treated as if they respected the borders of the nation states - as if the Danes, for example, had always spoken Danish. From this perspective, the old word order was supplemented and subsequently defeated by a new word order.

Even if we look only at the national languages, different routes may be posited as leading to the word order change. Gertrud Pettersson (1988) points to the old construction involving a preposed negation (or other constituent) in subjectless sentences, so that the verb is always in second position, as the 
source of the SCWO. However, she does not think that an internal linguistic source is the sole explanation for the development, and consequently refers to the demands on written language as the driving force. Alternatively, Cecilia Falk (in her 1993 dissertation using the Principles and Parameters approach) embeds the problem of the new word order in a hierarchy stating that the decisive factor is internal: the disappearance of person agreement. Pettersson objects to the older theory of foreign influence, while Falk apparently works within a paradigm where no such thing as external factors exists.

The older theory may in fact not be incompatible with the newer ones. Larsson (1931) points to Latin and Middle German influence, but it is not obvious why such influence would lead to the SCWO rather than, for instance, a verb-final construction. On the other hand, once the written language is drawn into the picture, foreign influence becomes natural. The written language to be imitated was Latin for the Germans, and the German influence on Danish and Swedish was not confined to the spoken mode. Thus Latin influence may be discerned in specific constructions in Danish, as well as in efforts to create written language means to distinguish the various types of subordination after the Latin model.

The dialect evidence and the sociolinguistic facts presented above all support the assumption of a specific development of the written language in that they point towards the spoken language as more archaic - containing more $\mathrm{MCWO}$ - than the written language, the Jutland dialect as preserving the old word order in many subordinate clause types, and Copenhagen speech as manifesting the remnants of the old order, though in two subordinate clause types only. This would point towards a complex interplay between the spoken language and the written norm once this was clearly established as such, with the written norm progressively wiping out the MCWO alternative. The MCWO would, as it were, be 'the speech order' and the SCWO consequently a specific written language signal for subordination. According to this view, the two word orders would have co-existed in free variation from period II until the end of the 19 th century. Towards the middle of this phase, the SCWO could be used as a means to signal a learned or controlled style (Holberg), while at the end of it, the SCWO had become the default standard, and it was the MCWO that was used for stylistic purposes such as making the prose more direct, more lively, in short more oral (Andersen, Grundtvig).

The introduction of universal schooling and the standardization which followed in the wake of the ensuing high literacy rates called for 'logic' in this 
case, as in so many others. 'Logic' in linguistic socialization invariably means to get rid of variation. One might speculate that it was the school teachers who started reserving the MCWO for main clauses, thus by the same token assigning to the SCWO the unique function of signaling subordination. Simple pedagogy demands easy rules that can be learned quickly and that simplify the correction of school assignments. The low MCWO percentages from 1800 onwards tally with the rise of literacy in the beginning of the 19th century.

An apparent problem for this type of reasoning is that the Nordic languages chose a feeble signal instead of the strong one. If a simple rule is what is desired, the verb-final construction is more easily learnable, and it was alive in the written law texts, including a prominent and widely-circulated law from the middle of the 17th century. It is worth speculating whether the verb-final construction was discarded because it was felt to be German or too solemn (viz. legal) in its connotations. Interestingly, we have first-hand evidence that the verb-final construction was avoided at the end of the 17th century, when countess Leonora Christine herself corrected her manuscript of the Jammers Minde (Glismann 1997). Evidently it was felt to be wrong (whether 'too German' or simply incorrect) a century before the general literacy rates began to rise drastically. This would mean that the strong signal was in fact not an option when the school teachers took over.

Another problem is that we would expect the alternative construction types to have been commented upon by prescriptive grammarians. Jens Høysgaard in $\$ 392$ and $\$ 394$ of his 1747 Accentuered og raisonnered grammatica (Accented and Reasoned Grammar) indeed recommends the SCWO for subordinate clauses. However, this is the only mention we have been able to find, though we have searched through all the available school grammars from the 19th century. The reason could simply be that the construction was taught as a matter of course. This would certainly be in the tradition of Danish mother tongue standardization, which presupposes rather than explicitly forbids (cf. Kristiansen 1990).

Ultimately, we suggest that the various explanatory approaches are not mutually exclusive, but rather may be integrated. Once the construction has been analyzed and documented throughout all the Germanic speaking speech communities, we shall know what the linguistic hierarchy is (cf. Falk 1993). Then we can proceed to use the dialect geographical evidence and a language contact approach to evaluate any claims as to external influences, while the national language paradigm can be called upon to explain specific local 
developments (as for instance the case of Icelandic, which preserves the old word order). Finally, a critically-informed internal colonization approach must specify the relationship between the dialects and the standard language.

\section{Notes}

* The authors wish to thank Eva Skafte Jensen who did much of the work with the excerpting and the computation which is documented in Figure 1, Marianne Johansen and Charlotte Buch Simonsen who prepared the Copenhagen data, and Gertrud Pettersson and the editors, in particular Lene Schøsler and Susan Herring, for their indispensable comments on a first and second draft. Needless to say and all that....

1. Jespersen has written valuable papers on Danish, e.g. Jespersen (1895) (about 'og' (and) = 'at' (that)) and Jespersen (1934) about the Danish genitives, but Danish grammar was not his main concern.

2. "Det vil da også vise sig, at mens sætningerne uden fremdraget biord o.s.v. i reglen står isolerede, skarpt adskilte fra de omgivne sætninger af samme art ved tonefald og pavse, så er de med fremdraget biord o.s.v. næsten altid en del af en sætningsforbindelse, hvori der tillige findes en sætning af en anden art, og meningsforholdet er da for det meste det, at hine føles som hovedtanken og disse sidste som bitanker. Således frembyder sig i det hele naturligt de bekendte navne hovedsætning og bisætning for disse to sætningsformer, hovedsætning for den uden fremdraget biord (men ellers i det hele smidigere ordstilling) og bisætning for den med fremdraget biord (men i фvrigt stivere ordstilling, se $\S 300$ )."

3. The first to formulate the descriptive rule precisely seems to have been Kinch (1856), but Kinch's rule is a refined version of rules in earlier grammars written by teachers at the Latin schools, first and foremost Binzer (1845/1852).

4. "Eksemplerne i $\S 64$ er alle taget fra selvstændige Sætninger. Inddrager man i Undersøgelsen de Sætninger, der staar som Led, vil man finde, at de fleste af disse har en simplere Struktur, idet de ikke har noget Fundamentfelt; desuden har de en anden Orden af Leddene i Neksusfeltet. Det er altsaa kun Indholdsfeltet, der er nøjagtigt ens i alle Sætninger, og vi maa opstille to Hovedtyper af Sætninger: Bisætninger (\$72), der mangler Fundamentfelt og har Ledstillingen s-a-v (a-s-v) i Neksusfeltet, og Hovedsætninger (\$73), der har Fundamentfelt (selv om det ikke altid er udfyldt) og Ledstillingen v-s-a (v-a-s) baade i Neksusfelt og Indholdsfelt."

5. Beckman immediately notes that this criterion may fail, since the conjunction may be missing or may be introducing a main sentence (op.cit.: 235).

6. From the Reformation until the late part of 19th century, the Neogothic type was the ordinary type in handwriting, and blackletters dominated in book printing.

7. The texts excerpted are listed with full bibliographical details in the appendix.

8. There are exceptions, prominent among them Ebert (1992, cf. p.202ff). 
9. Final clauses give an account of the purpose of or the intention behind the actions described in the main clause. They are most often introduced by 'for at' (equivalent to English 'so that').

10. This fact points to a development which is interesting in its own right and might be relevant to the problem at hand as well: the functional and semantic specification of subordinating conjunctions, such that they eventually end up being confined to particular subtypes. The all-purpose conjunction at may be supplemented by så when introducing consecutive subordinate sentences and by for when introducing final clauses (Pedersen 1996).

11. We excerpted 80 pages from period I without encountering any clear examples of SCWO. There are some other word order differences between this period and later ones. Among other things, subjectless clauses are frequent, and word order in these clauses is different.

12. Vedel 1581 is omitted here because it is a rather short text, and many sentence types are not represented in it.

13. The German SCWO with a final finite verb seems to be established in Luther's prose in the 1520's. A comparison between Christiern Pedersen's translation (1531) and Luther's original version reveals that Christiern Pedersen's text is a very free adaptation. Where we do have a direct translation of the original, the Danish word order does not agree with the German one. One finds MCWO where Luther has final finite, and examples of final finites in the Danish text where there is no source of it in Luther.

14. This percentage is significantly higher than that in Figure 1. This means that almost all the MCWO instances in the Petersen text are of the nominal that type.

15. Verb-final constructions may be found in other texts as well, but in smaller numbers (cf. note 12 above).

16. Emphasis is in the original.

17. A fuller account of this part of the investigation may be found, along with further documentation, in Gregersen and Pedersen (1997).

18. The category consists of clauses that cannot be interpreted unequivocally as either final or consecutive.

19. The Bornholm figures may be explained (away) as being due to the original field worker's lack of interest in syntax (cf. Pedersen 1996:244).

20. Pettersson (1988:159) states that the verb-final construction was quite normal as late as the beginning of the 18th century in Swedish, but goes on to add: "at least in certain genres", and that remark refers mainly to the legal text type (cf. Nyström 1985).

21. Peter Auer, personal communication.

22. The Norwegian case is an exception. 


\section{Appendix: Sources excerpted (in chronological order)}

Pedersen, Christiern (1515): Jærtegns Postil, C.J. Brandt og R.Th. Fenger (udg.): Danske Skrifter bd. II,1. Kbh. 1851.

Pedersen, Christiern (1529): Det nye testamente, C.J. Brandt og R.Th. Fenger (udg.): Danske Skrifter bd. III. Kbh. 1852.

Pedersen, Christiern (1531): Om børn ath holde till Scole och Studium, Brandt og Fenger (udg.): Danske Skrifter bd. IV. Kbh. 1854.

Tausen, Hans (1535): De fem mosebøger, Bjørn Kornerup (udg.): DSL facsimile-udgave. Kbh. 1932.

Tausen, Hans (1539): Postil, Bjørn Kornerup (udg.): DSL facsimile-udgave. Kbh. 1934.

Palladius, Peder (1543) Visitatsbogen, Lis Jacobsen (udg.): Danske Skrifter, UjdSFacsimileudgave Kbh. 1925-26.

Vedel, Anders Sørensen (1575): Oversættelse af Saxos: Den danske Krønike, Israel Levin (udg.), Kbh. 1845-51.

Vedel, Anders Sørensen (1581) Om Den Danske krønicke/at bescriffue, Gustav Albeck (udg.) i: Humanister i Jylland, 130-52, Munksgaard, Kbh. 1959.

Chr. IV (1636-40): Breve, Bricka \& Fridericia (udg.) Kong Christian den Fjerdes Egenhæendige Breve, bd. 4, Kbh. 1969.

Brochmand, Jesper (1638): Huspostil.

Syv, Peder (1663): Om det Cimbriske Sprog, Henrik Bertelsen (udg.): Danske Grammatikere bd. 1. København 1915 (1979).

Holberg, Ludvig (1732-35): Dannemarks Riges Historie.

Holberg, Ludvig (1748): Epistler bd. I., udg. v/ F.J. Billeskov-Jansen. Kbh. 1944.

Sneedorff, J.S. (1775-77): Den patriotiske Tilskuer and Om den Borgerlige Regiering, Sneedorffs samtlige Skrivter bd. II. Kbh. 1776.

Malling, Ove (1777): Store og Gode Handlinger af Danske, Norske og Holstenere, udg. DSL v/ Erik Hansen. Kbh. 1992.

Grundtvig, N.F.S. (1816-19): Danne-Virke.

Grundtvig, N.F.S. (1824-25 \& 1837-38): Prædikener, Chr. Thodberg (udg.): Grundtvigs Prædikener bd. 3 \& 11. Kbh. 1986.

Grundtvig, N.F.S. (1832): Nordens Mythologi.

Andersen, H.C. (1846): Brevveksling Collin bd. II., udg. v/ C. Behrend og H. TopsøeJensen. Kbh. 1934.

Andersen, H.C. (1835-72): Eventyr bd. I-II., udg. DSL v/ E. Dal og E. Nielsen. Kbh. 196367.

Kierkegaard, Søren (1855): Øieblikket. Kbh. 1855.

Petersen, N.M. (1866): Bidrag til den oldnordiske Literaturs Historie. Kbh. 1866.

Brandes, Georg (1871): Hovedstromninger i det 19de Aarhundredes Litteratur, Emigrantlitteraturen. Kbh. 1872.

Hørup, Viggo (1889-90): Karsten Thorborg (udg.): Hørup i Breve og Digte. Kbh. 1981.

Hørup, Viggo (about 1880): V. Horup i Skrift og Tale bd. I-III, v/ Vilh. Nielsen et al. Kbh. 1902-1904.

Brandes, Georg (1906-10): Samlede Skrifter bd. 18. Kbh. og Kristiania 1910.

Henningsen, Poul (1919-57): Artikler, Kulturkritik bd. I-IV, v/ C.E. Bay og O. Harsløf. Kbh. 1973. 


\section{References}

Andersson, Lars-Gunnar. 1975. Form and Function of Subordinate Clauses. Gothenburg Monographs in Linguistics 1. University of Göteborg: Department of Linguistics.

Beckman, Natanael. 1916. Svensk Språklära för den högre elementarundervisningen. 9th edition. Stockholm: Bonniers 1964.

Bernstein, Basil. 1959. "A Public Language: Some Sociological Implications of a Linguistic Form”. Class, Codes and Control, ed. by Basil Bernstein, Vol.1, 42-60. London: Routledge and Kegan Paul 1971.

Binzer, H.F. 1845. Dansk Sproglære. 2nd edition 1852.

Blatt, Franz. 1957. "Latin Influence on European Syntax". The Classical Patterns of Modern Western Civilization: Language, ed. by Louis Hjelmslev and Carsten Høeg. Proceedings of the Second International Congress of Classical Studies, 33-69. København: Nordisk Sprog- og Kulturforlag.

Broby, Erik. 1867. Modersmålets Sætningslære. København: Vissings forlag.

Crowley, Tony. 1989. The Politics of Discourse: The Standard Language Question in British Cultural Debate. London: Macmillan.

Diderichsen, Paul. 1946. Elementær dansk Grammatik. København: Gyldendal.

Diderichsen, Paul. 1965. "Synspunkter for dansk sproglære". Det danske sprogs udforskning $i$ det 20. århundrede, ed. by Jørgen Larsen, Christian Lisse og Karl Martin Nielsen, udgivet af Selskab for Nordisk Filologi, 142-211. København: Gyldendal.

Ebert, Robert Peter. 1992. "Internal and External Factors in Syntactic Change in an Historical Speech Community". Internal and External Factors in Syntactic Change, ed. by Marinel L. Gerritsen and Dieter Stein, 201-228. Trends in Linguistics, Studies and Monographs 61. Berlin/New York: Mouton de Gruyter.

Falk, Cecilia. 1993. Non-referential Subjects in the History of Swedish. Diss. Department of Scandinavian Languages: University of Lund.

Friis, Oluf. 1937-45. Den danske litteraturs historie, I: Fra Oldtiden indtil renæssancen (c.1615). København: G.E.C. Gad 1975.

Glismann, Otto. 1997. Om at 'handle mis' med en klassiker. Sprog og stil $i$ “Jammers Minde" - En tekstkritisk unders $\phi g e l s e$ af udgaverne. Private publication: Birkerød.

Gregersen, Frans. 1991. "Relationships Between Linguistics and Applied Linguistics: Some Danish Examples". Foreign/Second Language Pedagogy Research. A Commemorative Volume for Claus Farch, ed. by Robert Phillipson, Eric Kellerman, Larry Selinker, Mike Sharwood Smith and Merril Swain, 11-28. Clevedon: Multilingual Matters.

Gregersen, Frans. 1995. "Some Problems with the Labovian Paradigm". Verhandlungen des Internationalen Dialektologenkongresses Bamberg 1990, Band 4, ed. by Wolfgang Viereck, 35-48. ZDL-Beiheft 77. Stuttgart: Franz Steiner Verlag.

Gregersen, Frans and Inge Lise Pedersen. 1990. "Copenhagen as a Speech Community". Storstadsspråk och storstadskultur $i$ Norden, Meddelanden från Institutionen för nordiska språk vid Stockholms Universitet (MINS) nr. 34, ed. by Kjellars Berge and Ulla-Britt Kotsinas, 57-69. Stockholm.

Gregersen, Frans and Inge Lise Pedersen (eds.). 1991. The Copenhagen Study in Urban Sociolinguistics. Institut for dansk Dialektforsknings publikationer, Serie A. nr.30. København: C.A.Reitzel. 
Gregersen, Frans and Inge Lise Pedersen. 1997. "Hovedsætningsordstilling i underordnede sætninger." Danske folkemål 39, 55-112. København: C.A. Reitzel.

Heltoft, Lars. 1986. Topologi og syntaks. En revision af Paul Diderichsens sætningsskema. NyS 16/17. 105-130.

Hjelmslev, Louis. 1928. Principes de grammaire générale. Det Kgl. Danske Videnskabernes Selskab, Historisk-filologiske Meddelelser, Bind XVI, nr.1, 2nd edition. København: Munksgaard 1968.

Høysgaard, Jens Pedersen. 1747. Accentuered og raisonnered grammatica, Danske Grammatikere vol. 5, ed. by Henrik Bertelsen. København 1923 (1979).

Jespersen, Otto. 1895. "En sproglig værdiforskydning. $O g=a t "$ ". Dania 3.145-182.

Jespersen, Otto. 1934. "Gruppegenitiv på dansk". Studier tilegnede Verner Dahlerup, Tillægsbind til Danske Folkemaal 8.1-7.

Kinch, J. 1856. Dansk Sproglare til Skolebrug. Ribe.

Kristiansen, Tore. 1990. Udtalenormering $i$ skolen. Skitse af en ideologisk bastion. København: Gyldendal.

Labov, William. 1984. "Field Methods of the Project on Linguistic Change and Variation". Language in Use, ed. by John Baugh and Joel Scherzer, 28-53. New Jersey: Prentice Hall.

Larsson, Carl. 1931. Ordföljdsstudier över det finita verbet $i$ de nordiska fornspråken, I, Uppsala Universitets Årsskrift. Uppsala: Lundquistska Bokhandeln.

Mikkelsen, Kr. 1911. Dansk Ordföjningslære. Reprint Hans Reitzels forlag. København 1975.

Milroy, Lesley. 1980. Language and Social Network. London: Basil Blackwell.

Milroy, Lesley. 1987. Observing and Analyzing Natural Language. London: Basil Blackwell.

Møller, Erik. 1991. "Narratives in the Sociolinguistic Interview". The Copenhagen Study in Urban Sociolinguistics, part 2, ed. by Frans Gregersen and Inge Lise Pedersen, 241335. Copenhagen: C.A. Reitzel.

Møller, Erik. 1993. Mundtlig fortælling - fortællingens struktur og funktion i uformel tale. Institut for Dansk Dialektforsknings publikationer, Serie A, nr. 31. Copenhagen: C.A. Reitzel.

Nygaard, Marius. 1900. "Verbets stilling i sætningen i det norrøne sprog". Arkiv för nordisk filologi XVI. 209-241.

Nygaard, Marius. 1966. Norrøn syntax. Oslo: Aschehoug og Nygaard.

Nyström, Ingegerd. 1985. Studier i äldre nysvensk syntax II. Ledstruktur och ledföljd $i$ bisatser. Meddelanden från Institutionen för nordiska språk och nordisk litteratur vid Helsingfors Universitet, Serie A, nr.4: Helsingfors.

Ong, Walter J. 1977. Interfaces of the Word. Studies in the Evolution of Consciousness and Culture. Ithaca: Cornell University Press.

Pedersen, Inge Lise. 1995. "Social Classification in a Gender Perspective". Verhandlungen des Internationalen Dialektologenkongresses Bamberg 1990, Band 4, ed. by Wolfgang Viereck, 106-117. ZDL-Beiheft 77. Stuttgart: Franz Steiner Verlag.

Pedersen, Inge Lise. 1996. "Der kan jo være nogen der kan itte tåle det' Om hovedsætningsordstilling i bisætninger i danske dialekter". Studier $i$ talesprogsvariation og sprogkontakt. Til Inger Ejskjær på halvfjerdsårsdagen den 20. maj 1996, 242-251. 
København: C.A. Reitzels forlag.

Pettersson, Gertrud. 1985. "Bisatsstrukturen i äldre nysvenska. Några synspunkter på en avhandling från projektet Äldre nysvensk syntax“. Nysvenska Studier, Tidsskrift för svensk stil- och språkforskning 65.181-207.

Pettersson, Gertrud. 1988. "Bisatsledföljden i svenskan eller Varifrån kommer BIFFregeln?" Arkiv för Nordisk Filologi 103.157-180.

Platzack, Christer. 1987a. "Bisatser, huvudsatser och andre satser". Grammatik på villovägar, ed. by Ulf Teleman. Skrifter utgivna av Svenska Språknämnden 73. 79-86. Uppsala: Almqvist \& Wiksell.

Platzack, Christer. 1987b. "Huvudsatsordföljd och bisatsordföljd". Grammatik på villovägar, ed. by Ulf Teleman. Skrifter utgivna av Svenska Språknämnden 73. 87-96. Uppsala: Almqvist \& Wiksell.

Skautrup, Peter. 1947. Det danske sprogs historie, vol. 2. København: Gyldendal.

Teleman, Ulf. 1967. "Bisatsar i talad svenska". Svenskt talspråk. Fem studier, ed. by Gösta Holm, 160-203. Uppsala: Almqvist \& Wiksell.

von Polenz, Peter. 1978. Geschichte der deutschen Sprache, 9th ed. Sammlung Göschen. Berlin/New York: de Gruyter.

Wivel, H.G. 1901. Synspunkter for dansk sproglære. København: Det nordiske forlag. 
2f086f2c003b 8808 e6bce 4 dedaa 5 b 67 a

ebrary
$2 f 086 \uparrow 2 c 003$ b 8808 e6bce 4 dedaa 5 b 67a ebrary

$2 f 086 f 2 c 003 b 8808$ e 6 bce 4 dedaa 5 b 67 a

ebrary 